\title{
Transcranial Doppler in the blue stander: the platypnoea-orthodeoxia syndrome revisited
}

\author{
Jose Antonio Egido, ${ }^{1}$ Ana Maria Garcia
}

${ }^{1}$ Department of Neurology, Hospital Clinico San Carlos, Madrid, Spain

${ }^{2}$ Stroke Unit, Worcestershire Royal Hospital, Worcester, UK

\section{Correspondence to} Jose Antonio Egido, jegidoh@yahoo.com

Accepted 3 October 2014

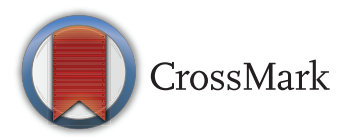

To cite: Egido JA, Garcia AM. BMJ Case Rep Published online: [please include Day Month Year] doi:10.1136/bcr-2014207440

\section{DESCRIPTION}

A young man was referred to our neurosonology laboratory after an endovascular closure of an ostium secundum interatrial communication. The procedure led to control of strenuous exercise dyspnoea. However, in the 1 month control follow-up visit the patient reported of shortness of breath when seated and standing, with a minimum right to left shunt in the bubble echocardiogram. On physical examination, cyanosis appeared only when standing, and oxygen saturation dropped to $70 \%$ from basal 99\%.

The patient was monitored for microembolic signals using transcranial Doppler sonography (TCD, videos 1 and 2) lying, sitting and standing.

A platypnoea-orthodeoxia syndrome (POS) was diagnosed. The syndrome is characterised by dyspnoea that occurs in the upright position and is relieved by recumbency (platypnoea) and a significant drop in arterial oxygen saturation when moving from the supine position to the upright position (orthodeoxia). Position-dependent right-to-left shunting appears to underlie in POS. ${ }^{1}$ Contrast-enhanced transoesophageal echocardiography (cTOE, agitated saline) is the preferred diagnostic modality when intracardiac shunting is suspected. However, TCD has shown a sensitivity of $97 \%$ compared to cTOE with non-significant difference; it is the diagnostic test in the case of pulmonary arteriovenous malformations complementary to pulmonary ventilation-perfusion tests; its reported specificity is $98 \% .^{2}$ Effective Valsalva manoeuvre increases the sensitivity, but $10 \%$ of population may not have a temporal acoustic window. Therefore, TCD should be recommended

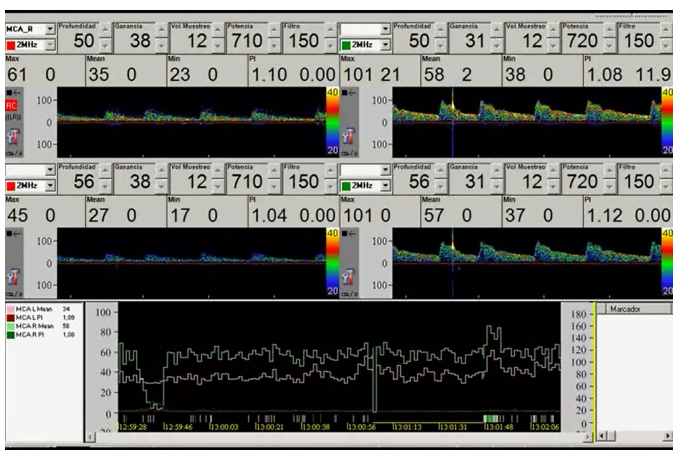

Video 1 TCD monitoring (at 50 and $56 \mathrm{~mm}$ of depth). Right middle cerebral artery is shown on the left side of picture (red boxes) and left middle cerebral artery is on the right side (green boxes). Patient is laying (13:01:13), sitting (13:01:45) and back again to supine position at 13:01:59. "Shower embolic pattern" appears without oxygen saturation drop.

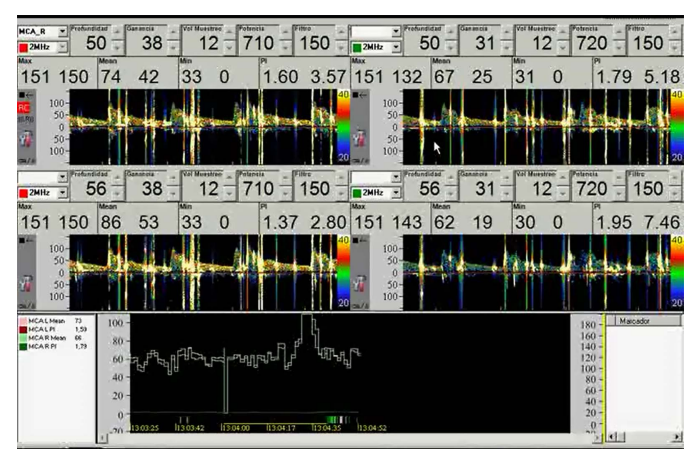

Video 2 At 13:04:29, patient was asked to stand from supine position. "Curtain pattern" (uncountable bubbles) was recorded, alongside with oxygen desaturation.

as the first choice for screening because of its simplicity, non-invasive character, low cost and ability to assess the patient quickly in the supine as well as upright position. $^{3}$

\section{Learning points}

Knowledge of the patient's history is pivotal in order to suspect platypnoea-orthodeoxia syndrome. The diagnostic test should be performed in the position that leads to dyspnoea.

- Transcranial Doppler with agitated saline contrast and Valsalva manoeuvre shows a sensitivity similar to contrast transoesophageal echocardiography.

- TCD does not require sedation and therefore allows the examination to be performed quickly in all three required positions.

Competing interests None.

Patient consent None.

Provenance and peer review Not commissioned; externally pee reviewed.

\section{REFERENCES}

1 Knapper JT, Schultz J, Das G, et al. Cardiac platypnea-orthodeoxia syndrome: an often unrecognized malady. Clin Cardiol 2014;9:1-5.

2 Gonzalez-Alujas T, Evangelista A, Santamarina E, et al. Diagnosis and quantification of patent foramenn ovale. Which is the reference technique? Simultaneous study with transcranial Doppler, transthoracic and transesophageal echocardiography. Rev Esp Cardiol 2011;64:133-9.

3 Komar M, Olszowska M, Przewlocki T, et al. Transcranial Doppler ultrasonography should it be the first choice for persistent foramen ovale screening? Cardiovasc Ultrasound 2014;12:16-21. 
Copyright 2014 BMJ Publishing Group. All rights reserved. For permission to reuse any of this content visit http://group.bmj.com/group/rights-licensing/permissions.

BMJ Case Report Fellows may re-use this article for personal use and teaching without any further permission.

Become a Fellow of BMJ Case Reports today and you can:

- Submit as many cases as you like

- Enjoy fast sympathetic peer review and rapid publication of accepted articles

- Access all the published articles

- Re-use any of the published material for personal use and teaching without further permission

For information on Institutional Fellowships contact consortiasales@bmjgroup.com

Visit casereports.bmj.com for more articles like this and to become a Fellow 